\title{
The Tragic Love of an Aristocratic Lady-----On Personality Distortion of Miss Emily \\ Zhi DENG
}

\author{
Foreign Languages School, Sichuan University, Chengdu, China, 610064 \\ daaimao@126.com
}

Keywords: family restriction; lover's disloyalty; gossip; personality distortion.

\begin{abstract}
In A Rose for Emily written by William Faulkner, the heroine Miss Emily, kills her lover and stores the corpse at home for several decades. Miss Emily seems morbid, however, she is a tragic character who calls for sympathy. This essay is in an attempt to construe her murder case as an outcome of personality distortion resulted from the family restriction, the lover's disloyalty and the town people's gossip. Under their combined pressure, Miss Emily fails to fulfill her desire for love and withdrew to solitude until death.
\end{abstract}

\section{Introduction}

Set in a small southern town in the United States around 1900's, the story, A Rose for Emily written by William Faulkner, is about an incredibly weird woman who kills her lover and keeps the corpse in her house until she herself dies. The heroine, Miss Emily Crierson is born into an aristocratic family with distinguished lineage and kept single till the age of thirty [1]. After her father dies, she falls in love with Homer Barron, a construction company foreman from the north. The town people are "sure that they were to be married" [2] (234). The northerner, however, disappears soon. When Miss Emily dies 30-odd years later, people enter her house and find the man lying dead in the bed from which "what was left of him, rotted beneath what was left of the nightshirt, had become inextricable" (236). According to Fatima [3], the reader who regards Emily as "sick" or "demented" does not understand the true depth of Emily's nature. Although her macabre behavior is astonishingly strange, she is determined to fulfill her desire for love and live her own life. She fails, however, due to the formidable conspiracy of her father's excessive control, Homer Barron's disloyalty and the town people's gossip. With their coexistence in her life, she falls morbid and tries to eternalize her pure love at the cost of Homer's death.

\section{Family Restriction}

As an old-typed aristocrat, Mr.Grierson--Emily's father--"held themselves a little too high for what they really were" (232). His stubborn exclusiveness prevents him and his daughter from communication with the ordinary people in the town. Confinement to her austere father turns Emily from a naïve girl into a 30-year-old eccentric spinster. Imagination allows us to consider Emily as an innocent and happy girl in her childhood and as any ordinary one in her adolescence. Courted by some boy who manages to dance with her, she might have been fallen in love with him. But her intimidating father, "a spraddled silhouette...clutching a horsewhip" (232) in the town people's memory, thinks that "none of the young men were quite good enough for Miss Emily" (232) and drives away all of them. Under such circumstance, weak and pitiful Emily, "a slender figure in white" (232) cannot help but succumb to the arbitrary manipulation from her father. Her personality, however, changes. She becomes unsociable in her long-time solitude. She turns out aloof and haughty, often carrying "her head high enough" (233). Her superiority seems "as if she demanded more than ever the recognition of her dignity" (233). "So when she got to be thirty and was still single, we were not pleased exactly" (233). The town people begin to regard her as arrogant and eccentric. Emily's father, as the cause of her personality transformation, ruins her private life by robbing her of marriage and happiness. Therefore, when the father dies, Emily "dressed as usual 
and with no trace of grief on her face" (232) and embarks on seeking her love and trying to live her own life. After a long time of recovery, she started to take on a new look indicated by her cut hair "making her look like a girl, with a vague resemblance to those angels in colored church windows" (232). As she does not stoop to love any young man in the town, she eventually falls in love with a Yankee from the north, Homer Barron-"a big, dark, ready man, with a big voice and eyes lighter than his face" (233).

\section{Lover's Disloyalty}

Homer likes her but he will not marry Emily. His disloyalty proves to be a catalyst in changing Emily from a simple lover to an appalling killer. According to Paul Plagiarist, "Homer Barron, lived in the present, ready to take his pleasure and depart, apparently unwilling to consider the possibility of defeat by tradition (the Griersons)"[4]. As a foreman of a construction company, he leads a mobile life across the country. "Contracts" (233) determine his destination; it is impossible for him to be bound to Emily who lives her whole life in a traditional southern town of immobility. In addition, "he liked men, and it was known that he drank with the younger men in the Elks" Club" (234). Thus the reader is able to conclude that Homer has a tendency to indulge in homosexuality. He will hardly cherish any true love for a woman. Therefore "he was not a marrying man" (234) and his companionship with Emily is no more love than flirtation that, by no means, leads to marriage. "Poor Emily" (233), people whisper when they "see him (Homer Barron) and Miss Emily on Sunday afternoon driving in the yellow-wheeled buggy" (233). On the part of Emily, however, she falls in love with Homer heart and soul. Losing father who was her only relative in the town, she is eager to find another intimate person to cling to. As an unaffected girl, she is understood to hold dear her first love with Homer. Consequently, she becomes crazy for the foreman and fancies marrying him, irrespective of people's comments. She is found to have "been to the jeweler's and ordered a man's toilet set in silver, with the letters H. B. on each pieces" (234). So, when Homer is finally going to desert her, Emily slumps down to the bottom of despair that turns her intense love into unquenchable hatred. She determines to murder Homer and keep his corpse at home. In this way, she protects and perpetuates her pure love by being still close to him. What happen subsequently are revealed to the reader in their sequence. Looking "back at him (druggist), erect, her face like a strained flag" (233-234), she vanquishes the druggist with an invincible toughness to buy the arsenic; she forces the four men to sprinkle lime about her house to cover the "smell" out of Homer's corpse and creep away in horror at the sight of "her upright torso motionless" (232) behind the window in the depth of midnight; Emily's hair turns gray until it is "vigorous iron-gray, like the hair of an active man" (235), a hint of psychological turn from innocent weakness to perverted stiffness.

\section{Town People's Gossip}

As the reader may reasonably imagine, another element that gives rise to Emily's retaliatory murder is gossip and obstruction from the town people in her loving affair with "a day laborer" (233). There are two groups in these town people: one is "we"-the lower class; the other is the "ladies" and "older People" - aristocrats. The former tend to spread wishful and guessing remarks of good will sometimes ("she will marry him." (234)) and of malicious intention at other times ("she will kill herself" and we said it would be the best thing." (234)). The latter plot to stop Emily by sending for her cousins because they think that Emily's loving Homer is to "forget noblesse oblige" (233), giving "a disgrace to the town and a bad example to the young people" (234). Emily, despite their combined pressure, chooses to go her own way to fail in an unpaid love. She loses face in the town, being the last aristocratic member of the Griersons. Therefore she inevitably retaliates upon Homer to salvage her dignity. Another outcome produced from people's gossip and impediment is Emily's imperviousness she uses to preserve her privacy and pride. She does not appear on the streets in a stretch of almost six months after Homer Barron is killed. For six or seven 
years, she meets only children on Sundays for china-painting lessons. After her pupils grow up, her front door remains closed until the deputation of the town authority pay a visit for tax. But years of isolation deprive her of awareness of what has changed and what is happening in the town. She insists, "I have no taxes in Jefferson" (231) and asks the deputation to see Colonel Sartoris who "had been dead almost ten years" (231). She indeed becomes a "tradition" in the town. Furthermore, her imperviousness leads to her morbidity that is disclosed in her rejection to accept free post deliver. She "alone refused to let them fasten the metal numbers above her door and attach a mailbox to it. She would not listen to them" (235). Resisting the social and historical development turns her to a walking corpse as irresponsive to surrounding changes as that corpse of Homer lying upstairs in her house. Eventually she declines to a macabre figure - a sign of death. "Her skeleton was small and spare; she looked bloated, like a body long submerged in motionless water; her eyes looked like two small pieces of coal pressed into a lump of dough" (230). In conclusion, Eric Knickerbocker suggests that "the gossipy nature of a Southern town where everyone knows everyone else and noisy neighbors speculate about the affairs of Miss Emily" [5] plays a crucial role in her murder of Homer and her contortion in terms of personality.

\section{Conclusion}

Contrary to Terry Eagleton's assertion in the idea of Culture "nature has the final victory over culture" [6] (87), Miss Emily is defeated by cultural elements represented by the imprisonment from her aristocratic family, a cuckolding lover and the devastating remarks and actions of the inquisitive people in the town. Although she tries to perpetuate her chaste love by killing Homer and storing his corpse at home for several decades, she cannot ultimately win in her fight against cultural and social restrictions. At an early age of "about forty" [7], she retires into an antiquated life and remains there till death.

\section{References}

[1] Woodward Robert H, the Chronology of 'A Rose of Emily' J. Exercise Exchange. XIII No. 2 (1966) 17-19.

[2] Faulkner William, a Rose for Emily, in: Jamesk Bowen and Richard VanDer Beets (Eds.), American Short Fiction: Readings and Criticism, the Bobbs-merrill Company, Inc., New York, 1970. (The number in the bracket refers to the page of the fiction. Citation of the references from the same fiction is omitted in the following paragraphs in this article.)

[3] Information on http://www.tqnyc.org/NYC040522/shortstories/roseforemily

[4] Information on http://www.andover.edu/library/AcadInteg/rose_emily.htm

[5] Information on http://www.mrrena.com/misc/emily.shtml

[6] Eagleton Terry, the Idea of Culture, Blackwell Publishers Ltd., UK, 2000.

[7] Woodward Robert H, the Chronology of 'A Rose of Emily' J. Exercise Exchange. XIII No. 2 (1966) 17-19 